\title{
ADVANCING THE PRACTICE OF PERFORMANCE MONITORING \& EVALUATION IN OCEAN PLANNING
}

December 2016

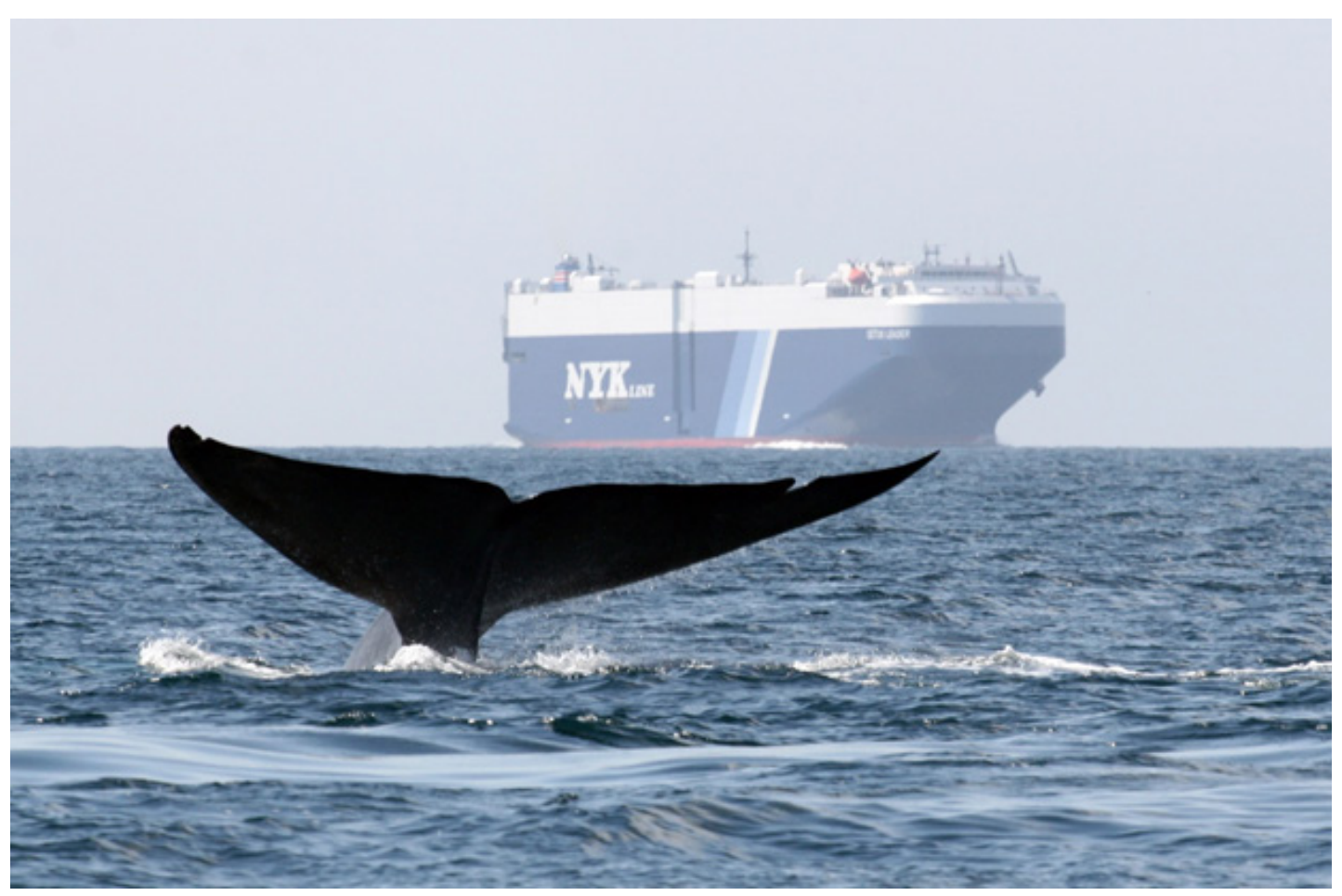

Prepared by: 


\section{ABSTRACT}

A substantial body of literature from the broader planning discipline identifies performance monitoring and evaluation (PM\&E) as the engine of the adaptive management cycle. In ocean planning, ideally PM\&E is integrated throughout the cycle, enabling a plan to identify and respond to changing conditions and, ultimately, to evolve iteratively toward its goals. However, planning authorities face a variety of challenges on the ground, which leads to PM\&E seldom being thoroughly considered early in the planning process, instead typically relegated to less than rigorous treatment in later implementation phases.

This paper acknowledges the barriers to effective PM\&E integration and explores strategies for advancing its practical application in ocean planning. The intent is to promote discussion among ocean planning practitioners and stakeholders about this critical component as new ocean plans come on line and existing plans are updated.

\section{ABOUT SEAPLAN}

SeaPlan, a nonprofit ocean science and policy group established in 2006 , collaborates with government agencies, marine industries, conservation interests and the scientific community to advance the practice of marine spatial planning. SeaPlan was instrumental in supporting Massachusetts' development of the nation's first comprehensive ocean management plan in 2009 and its review and revision in 2015, including assistance developing the plan's performance monitoring and evaluation framework. SeaPlan's work also includes significant technical and strategic support for the Northeast and Mid-Atlantic Regional Planning Bodies' efforts to develop the Northeast Ocean Plan and Mid-Atlantic Regional Ocean Action Plan.

\section{ACKNOWLEDGEMENTS}

We would like to thank several fellow practitioners whose ideas and reflections contributed greatly to this paper, including Steve Diggon, John Bones, David Blatt, Brian Thompson, Leo Asuncion, Justine Nihipali, Patty Snow, Andy Lanier, Jen McCann, Paul Gilliland, and Jen Hennessey. Special thanks to Charles Ehler for his always provocative and constructive perspective and contributions. Thanks also to Kate Longley-Wood (Senior Project Manager), lan Mogavero (Deputy Director), and Molly Morse (Project Associate II), who provided substantial review and input. 


\section{TABLE OF CONTENTS}

ABSTRACT

INTRODUCTION

ADVANCING PERFORMANCE MONITORING AND EVALUATION IN PRACTICE

MOVING FORWARD

APPENDIX A. PLANNING RESOURCES

APPENDIX B. MASSACHUSETTS PM\&E FRAMEWORK 


\section{INTRODUCTION}

\section{PERFORMANCE MONITORING \& \\ EVALUATION - THE ENGINE FOR ADAPTIVE MANAGEMENT IN THEORY}

Complex, dynamic marine systems pose inherent uncertainty for managing ocean uses and resources. Marine spatial planning, or ocean planning, aims to account for this by incorporating adaptive management into the ocean planning cycle. This iterative process aims to improve management outcomes over time by observing changed conditions, assessing the relative effectiveness of management measures, and responding with adjustments to the plan. While adaptive management has been part of the environmental and natural resource management dialogue for decades,,$^{1,2}$ considerable discussion continues to refine the approach and understand how to effectively apply it in practice. ${ }^{3,4,5}$

This paper focuses on the applied practice of ocean plan performance monitoring and evaluation (PM\&E), operationally the engine of the adaptive management cycle, as a key component of the overall ocean planning process. (Figure 1).

Generally, the ocean planning community recognizes two main aspects of $P M \& E$, which guide planners in the overall assessment of the ocean plan and provide information to inform plan updates or revisions.

1 C.S. Holling, Adaptive Environmental Assessment and Management. (Chichester: John Wiley \& Sons, 1978)

2 Carl J. Walters, Adaptive management of renewable resources. (New York: MacMillan Publishing Company, 1986)

3 Rist, L., A. Felton, L. Samuelsson, C. Sandstrom, and O. Rosvall. "A New Paradigm for Adaptive Management." Ecology and Society 18 (2013): 63. doi: 10.5751/ES-06183-180463

4 Lindenmayer, D.B. and G.E. Likens. "Adaptive monitoring: a new paradigm for long-term research and monitoring." Trends in Ecology and Evolution 24(2009): 482-486. doi: $\mathrm{http}$ ://dx.doi.org/10.1016/j.tree.2009.03.005

5 Byron K. Williams. "Adaptive management of natural resources - framework and issues." Journal of Environmental Management 92(2011): 1346-1353. doi: https://dx.doi.org/10.1016/j.jenvman.2010.10.041

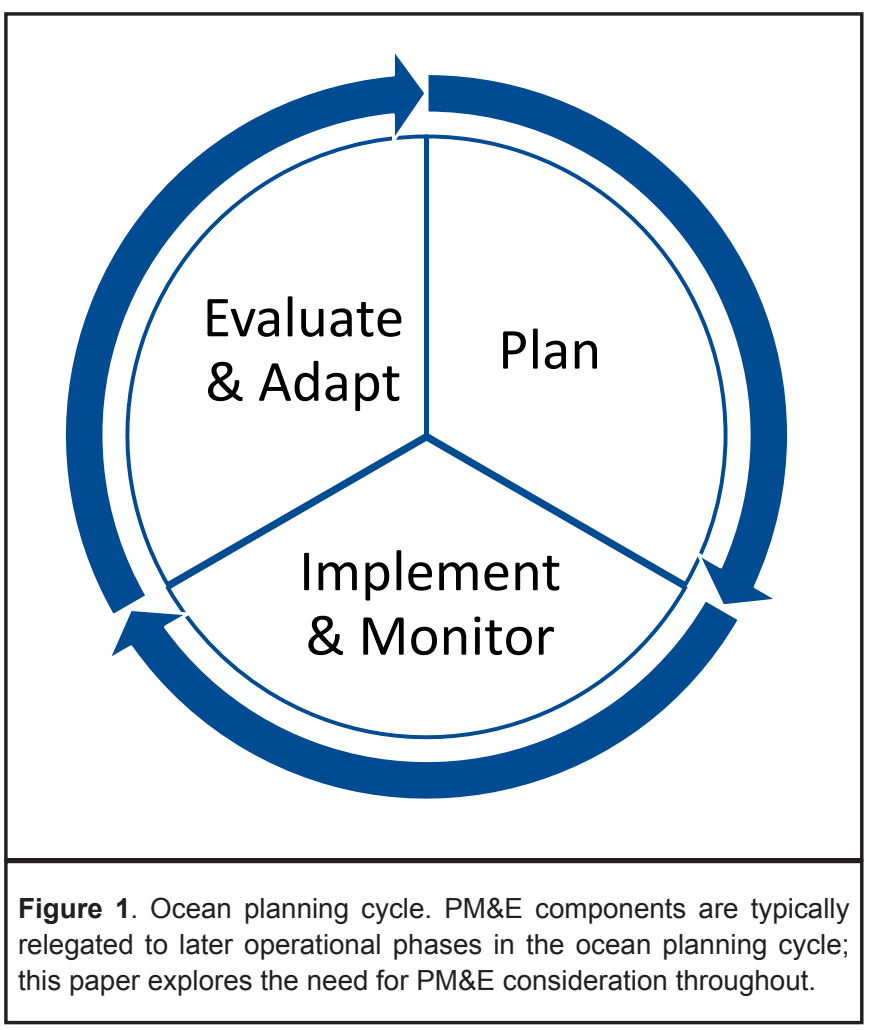

- Performance monitoring and evaluation refers to tracking and assessing progress in implementation of and compliance with an ocean plan's management actions. It establishes a system of accountability for specified planning authorities' actions that, together, constitute plan implementation and compliance (e.g., securing sustained funding, applying performance standards in reviewing proposed projects, etc.). Process assessment asks "Are planning authorities doing what the plan said they would do?"

- State-of-the-system monitoring and evaluation refers to tracking and assessing the condition of a particular suite of biophysical, socioeconomic, and institutional and governance systems the plan seeks to affect. ${ }^{6}$ Planners need to consider the condition of these systems over time to inform whether and how management

6 Some planning processes refer to the assessment of human and natural systems - biophysical, socio-economic, and institutional - as an ecosystem based management (EBM) approach. 
actions are updated, regardless of whether a change can be attributed to plan implementation. State-of-the-system assessment asks "How are the human and natural systems changing?" and "What response is needed from the plan?"

\section{APPROACHES TO ADAPTIVE MANAGEMENT AND PM\&E}

Comprehensive, centralized PM\&E: The topic of this paper, this strategy allows for consideration of how the whole ocean plan is performing relative to its overall goals and its multiple objectives. This approach relies on defining how information will be collected and provided to a centralized authority. This entity collaborates with other agencies and institutions to conduct stakeholder engagement and update the ocean plan when appropriate.

Explicitly decentralized PM\&E: Used in Hawaii, this strategy relies on existing monitoring and evaluation systems within agencies and depends on strong communication between agencies and the planning authorities to adapt to changing conditions. This strategy has the advantage of using existing processes but relies on experts in place to recognize and react to relevant trends, and does not provide explicit mechanisms to consider overall plan effectiveness.

Project-specific adaptive management: Used in Oregon's 2013 update to their Territorial Sea Plan, this strategy focuses on improving outcomes at the project level, rather than asking how the overall plan is working. The disadvantage to this approach is that it does not provide a mechanism to assess progress on the larger objectives of the plan and may miss trends occurring at scales beyond the project level.

Figure 2. Approaches to adaptive management and PM\&E.

\section{PM\&E IN PRACTICE}

Despite broad acceptance of the theoretical framework for incorporating comprehensive performance monitoring and evaluation, most ocean plans do not include fully operational PM\&E provisions, especially first generation plans. The East Inshore and Offshore Plans developed by the United Kingdom's Marine Management Organisation (MMO) and the four sub-regional plans developed by the Marine Planning Partnership (MaPP) for the North Pacific Coast of British Columbia are among the more advanced examples of integrating PM\&E considerations; yet planners involved are the first to recognize these are works in progress.

How can we as a community of ocean planning experts move the practice of PM\&E forward? The intent of this paper is to spark further conversation among practitioners to advance PM\&E integration in current and future ocean planning processes. To do this, we have compiled observations drawn from SeaPlan's collaborations to design and implement PM\&E approaches, informal consultation with several fellow practitioners with hands-on experience, and review of publicly available ocean planning related documents (See Appendix A, "Planning Resources").

\section{CONTEXT MATTERS}

It is important to acknowledge that each planning effort's particular institutional and political landscape presents both constraints and opportunities to incorporate and implement PM\&E on the ground. Highlighted below are a few noteworthy dynamics in ocean planning:

- The authorization or mandate for ocean planning often creates conditions that specify the nature of the process, including conferring certain authorities to planning officials, articulating guiding 
principles, and establishing a timeframe for plan development. Planning authorization that explicitly requires some form of review and evaluation typically facilitates more deliberate treatment of PM\&E, at least over multiple planning cycles.

- Transparency in ocean planning processes involves communication with and among authorities, funders, and/or stakeholders. Accountability in this system can drive the development of reporting practices, which can provide a mechanism for developing basic PM\&E components. However, the development of strong accountability mechanisms can be politically challenging.

\section{ADVANCING PERFORMANCE MONITORING AND EVALUATION IN PRACTICE}

The ocean planning community generally recognizes a set of broad principles to guide PM\&E, which are summarized in other documents. ${ }^{7,8}$ For purposes of this paper, we offer four main categories of generally accepted best practices for ocean planning PM\&E: planning integration, structural integration, implementation, and stakeholder engagement (Figure 3). Using generally accepted best practices in ocean planning PM\&E to frame the discussion, the paper explores challenges for their application and a variety of strategies practitioners have used to apply them.

\section{PLANNING INTEGRATION}

For PM\&E to be an effective engine of adaptive management, our thinking must shift from it as a deferred consideration for ocean plan implementation, toward an integrated overlay of the entire iterative planning cycle.

7 Charles Ehler, A Guide to Evaluating Marine Spatial Plans. (Paris: UNESCO, 2014). IOC Manuals and Guides, 70; ICAM Dossier 8

8 Barry D. Gold, M. Pastoors, D. Babb-Brott, C. Ehler, M. King, F. Maes, K. Mengerink, M. Müller, T.P.E. Cunha, M. Ruckelshaus, P. Sandifer, and K. Veum. 2011 Expert Paper: Integrated Marine Policies and Tools Working Group.

Figure 3. Summary of best practices for ocean plan performance monitoring \& evaluation by category. 


\section{BEST PRACTICE: PLAN FOR PM\&E FROM THE BEGINNING}

Challenges: The need to consider PM\&E early in the ocean planning cycle may seem self-evident, but for a variety of reasons, it is typically relegated to later phases. Often, planners focus on more immediately pressing plan development activities (e.g., getting buy-in on high level goals, developing a spatial management approach, addressing data gaps, etc.), leaving consideration of how to measure and communicate progress and incorporate learning into subsequent plan revisions as an afterthought for the implementation phase.

Strategy: Consider PM\&E activities as an integral part of scoping, scheduling, and budgeting the larger ocean planning process. Planning authorities typically develop at least a rough, updatable work plan that anticipates key activities, milestones

\section{SCARCE RESOURCES}

Typically, planners look for efficiencies to work within resource limitations as well as seek additional or new funding. Other mechanisms often considered to alleviate resource and capacity constraints include:

- Taking advantage of public-private partnerships when available to increase capacity. SeaPlan's work with Massachusetts is a good example of this strategy.

- Developing research priorities. These work to help drive research by academics that will support the plan, and their publication provides justification for researchers when applying for grants.

Figure 4. Scarce resources. and resource needs to conduct major activities over the phases of the planning cycle, such as data collection and stakeholder engagement. But PM\&E-related activities are often overlooked. The simple observation here is to include PM\&E in the overall ocean planning work plan.

Example: In the MaPP initiative, planning authorities anticipated that PM\&E would warrant considerable effort and engaged an expert contractor early in the planning process to develop capacity and resource estimates for implementing PM\&E-related activities. That up-front information informed budget tradeoff decisions going forward, including the choice to engage another contractor to pursue funding streams to support PM\&E.

Example: "Options for Developing Marine Spatial Planning in Long Island Sound", a pre-planning/ scoping document developed to support the Connecticut Blue Plan, is an interesting example of planners proactively considering when and how to incorporate PM\&E. The document identifies four options for PM\&E ranging from less structured and resource intensive to more comprehensive (as detailed in Ehler 2014).

\section{BEST PRACTICE: ENSURE PM\&E IS AN INTEGRAL PART OF THE OVERALL OCEAN PLANNING CYCLE}

Challenges: When PM\&E is not part of the initial conversations about an ocean plan, the plan framework takes shape without consideration of how it will be assessed. This poses challenges to developing the necessary structural components that support PM\&E in an ocean plan and ultimately hinders implementation of PM\&E processes.

Strategy: Organize ocean plan development to ensure that the outcomes of the plan can be monitored and evaluated. An important part of this is articulating linkages among key planning 


\section{A NOTE ABOUT CAUSALITY}

Defining linkages among plan components does not need to be conflated with implying direct causality between ocean plan implementation and observed changes in complex social and ecological systems, which are affected by many factors. The PM\&E process simply generates the information needed for planners to assess whether a particular change in the state-of-thesystem, regardless of its attributable causes, warrants a response during plan revision. For instance, global trends in shipping may result in a shift in priorities for that sector, which are then reflected in adjustments to relevant management actions.

Figure 5. Causality and PM\&E.

components so that PM\&E considerations are integrated throughout the ocean planning cycle - starting with initial goals and objectives setting, through implementation activities, and into plan revision. Investing the effort to define these relationships, as explicitly as possible, pays dividends not only by clarifying performance-related data collection needs and responsibilities, but also by establishing the rationale for evaluating progress toward plan goals and identifying the need for plan updates.

Example: Massachusetts'ocean plan demonstrates how PM\&E integration can improve through iterative planning cycles. The state's first generation ocean plan issued in 2009 did not explicitly facilitate PM\&E considerations from the start. It established three plan performance categories (environmental, socioeconomic, governance) and identified 20 associated indicators, and called for further PM\&E development in the future.
In the subsequent planning cycle that produced the 2015 ocean plan, Massachusetts developed a more robust PM\&E framework that reflects the relationship between the process and state-ofthe-system aspects of PM\&E; establishes clearer linkages among goals, metrics, and indicators; and generally identifies responsibilities and processes to feed information into overall plan assessment to guide future revisions. To facilitate the exercise of developing logical linkages among PM\&E components, planners found that posing simple questions was a useful device to clarify the context of plan goals and corresponding indicators and develop the linkages between each indicator and its specific metrics. See Appendix B for more information on the Massachusetts PM\&E Framework.

Example: By contrast, marine planning in England provides an example of PM\&E being considered early in the planning process, as mandated by the UK Marine Policy Statement. Due in part to this up-front treatment, the East Inshore and East Offshore ocean plans define specific "logic chains" that link the context, inputs, activities, outputs, and outcomes for each objective in the plan (Figure 6) (see the East Inshore and Offshore Implementation and Monitoring Plan for details).

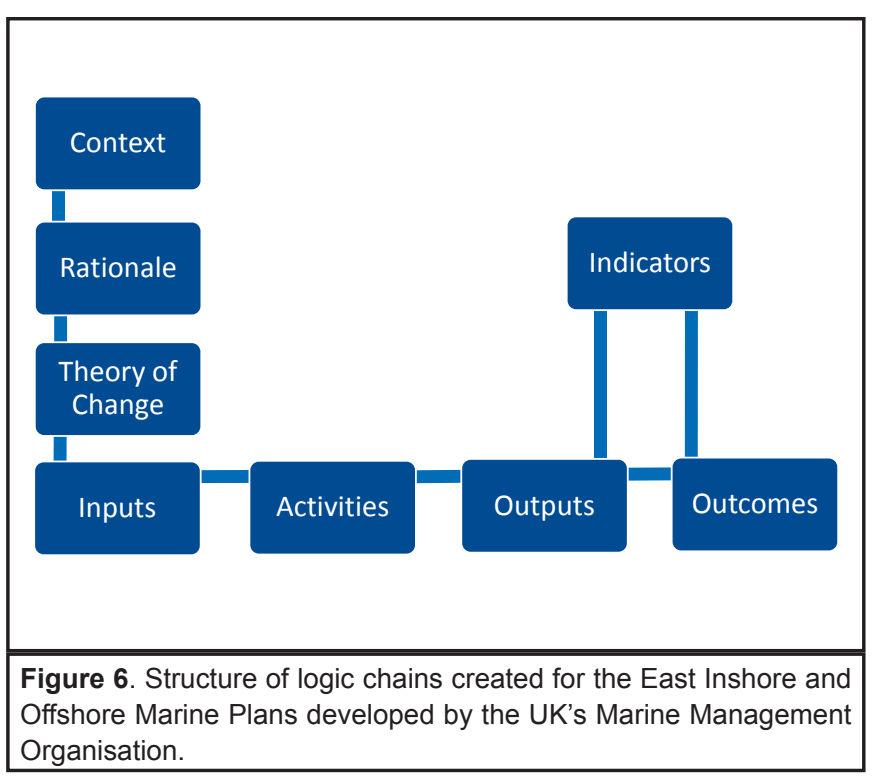

$5 \mid \mathrm{P}$ a g e 
Example: The 2013 amendment to the Oregon Territorial Sea Plan, which addresses offshore energy development, hard wires PM\&E into the planning cycle by establishing a trigger for plan updates. Based on project outcomes after plan implementation, a plan update can be triggered sooner than the predetermined 7-year update cycle if $1 \%$ of the planning area is in renewable energy development.

\section{STRUCTURAL INTEGRATION}

In theory, goals, objectives, management actions, indicators, and metrics comprise the operational components of an ocean plan and its PM\&E provisions. When optimally defined, the linkages between these components are apparent and the system facilitates implementation of monitoring and evaluation activities and plan updates or revisions.

\section{BEST PRACTICE: DEFINE SMART OBJECTIVES}

Ocean plan objectives translate the aspirational goals into more detailed actionable outcomes the plan seeks to accomplish. In the ideal, ocean plan objectives are Specific, Measurable, Achievable, Relevant, and Time-bound (SMART). ${ }^{9}$ These five attributes, reflected to the extent feasible for each objective, allow that objective to be monitored and evaluated.

Challenges: In practice, a range of political and institutional difficulties pose impediments to developing SMART objectives, making them more often the exception than the rule. Developing defensible SMART objectives, acceptable to the full range of stakeholder interests, can be a timeand resource-intensive undertaking. Measurable and time-bound criteria also introduce explicit ac-

9 Ehler (2014) provides a good overview of the application of SMART objectives in ocean planning and provides a number of sources that provide additional context on the development of SMART objectives in the larger management discipline. countability that political leaders may be reluctant to fully embrace. Beyond identifying issue or sector-specific objectives, ocean planning seeks to look comprehensively across sectors, including prioritizing objectives among numerous interests, to balance tradeoffs since resource constraints mean we "can't have it all." Given these kinds of challenges, ocean plans, especially first generation plans, are typically characterized by "lowest common denominator" generalized objectives.

Strategy: Invest the effort to define objectives up front that facilitate later monitoring and evaluation, to the extent feasible within the particular planning landscape.

Example: MaPP's four sub-regional ocean plans for the North Pacific Coast of British Columbia are an excellent example of planning authorities investing the time and expertise to develop SMART objectives (see the Haida Gwaii Plan linked in Appendix A for examples). In subsequent stakeholder vetting, however, the complexity and large number of SMART objectives, combined with limited time for review, tended to overwhelm stakeholders with detail making it challenging for them to offer specific input. Planners had to balance the need for meaningful stakeholder input while resisting the slide back to general, "lowest common denominator" objectives.

\section{BEST PRACTICE: DEVELOP ACHIEVABLE MANAGEMENT ACTIONS}

Ideally each ocean plan objective includes one or more management actions, which specifically explain how that objective will be accomplished. Each management action - collectively the substance of what will constitute plan implementation - identifies its rationale and implementing responsibilities. This specificity facilitates PM\&E efforts in both its performance (Is the management action getting done?) and stateof-the-system aspects (What effect is the action having on the human and marine systems?). 
Challenges: In practice, whether an ocean plan seeks to improve existing management function or create new management measures, a variety of constraints limit development of clear and achievable management actions. In some cases, even when political will and authority to support management actions are readily available, resources to commit to delivering on them may be scarce. Proposed management actions that involve creating new responsibilities, processes or bodies (e.g, working groups) may encountermoreobstacles.

Strategy: Develop management actions collaboratively with other implementing agencies and in consultation with stakeholders to identify cooperative actions that satisfy a given objective. These may be agency-to-agency and/or public-private actions.

Example: The U.S. Northeast and Mid-Atlantic Regional Planning Bodies - each with federal and state agency, tribal, and fishery council representatives - developed and incorporated numerous management actions for their respective ocean plans. Though the two processes varied, both involved considerable cross-agency consultation and stakeholder vetting to identify multiple management actions tied to each key topic area

\section{OPTING OUT OF SMART OBJECTIVES}

The planning processes for both Rhode Island and Washington State are examples of practitioners preemptively recognizing various constraints to come up with SMART objectives either the time and resources needed were seen as prohibitive or the process would likely impede the stakeholder engagement process. In these processes, planners proactively decided not to aim for time-bound measurable objectives from the start.

Figure 7. Opting out of SMART objectives. of the plan that responsible agencies expressed commitment to carry out.

Example: The state of Hawaii's Ocean Resources Management Plan developed management actions at the individual agency level to help ensure fit within each agency's mission and to be achievable within existing resources.

BEST PRACTICE: DEFINE INDICATORS \& METRICS WITH INCREMENTAL TARGETS AND BASELINE DATA

Indicators and metrics define how to measure progress on each management action (plan implementation) and the progress toward associated objectives (results and outcomes). Indicators and metrics are often used interchangeably and sometimes used in conjunction with one another. When used together, indicators and metrics often have a relationship analogous to objectives and actions. Indicators describe specific qualities of the social, natural, or institutional environment, which demonstrate progress on actions and objectives, while metrics are the specific variables used to measure indicators. For each indicator and/or metric, interim targets and baseline data provide the means to measure and determine progress.

Challenges: Planners encounter a variety of issues in their efforts to develop meaningful indicators and metrics. Particularly on the stateof-the-system aspects of PM\&E, planners often face resource constraints that limit additional data development and rarely provide opportunities to institute new integrated monitoring programs.

Strategy: Be opportunistic and work backward, as well as forward, to develop indicators and metrics that link to management actions. In other words, consider options to leverage data that are already available or being collected for indicator and metric purposes. 


\section{PRELIMINARY MONITORING AND EVALUATION PLANS}

During the plan development phase of the larger ocean planning cycle-as objectives, management actions and indicators are developed - the PM\&E needs for the implementation phase will become more apparent. This creates an opportunity to design preliminary monitoring and evaluation plans which can be refined closer to the start of ocean plan implementation.

Figure 8. Planning for implementation.

Example: In developing the Massachusetts Ocean Management Plan PM\&E framework (Appendix B), practitioners defined certain plan performance metrics that could be satisfied with information already being produced but not tracked. By routinizing its collection as part of normal agency business, for example through simple record keeping during permitting processes, this information can now be directly incorporated into the plan review cycle. For example, a metric related to assessing how the plan incorporates new knowledge to improve governance, in this case use of best management practices to avoid ocean use conflicts, can now be examined by tracking project proponents' conflict avoidance measures in permitting records.

\section{PM\&E IMPLEMENTATION}

The previous section discussed integrating PM\&E considerations as an ocean plan is being developed. Now we turn to aspects most commonly thought of as PM\&E, monitoring and evaluation, which happen during ocean plan implementation and cyclic review phases.

\section{BEST PRACTICE: MONITOR THE METRICS ESTABLISHED}

In the context of PM\&E, monitoring refers to the data tracking, collection, and management specifically for the metrics and indicators identified during ocean plan development and communication about them with stakeholders.

Challenges: In rare instances where an ocean plan clearly identifies objective-management action-metric-indicator groupings, corresponding monitoring can be relatively straightforward. However, given political and institutional considerations, it is more common for ocean plans to reflect mixed specificity in what constitutes measures of progress. "Lowest common denominator" objectives and management actions will translate into commensurately ambiguous metrics and indicators, which lead to difficulties developing and implementing effective monitoring programs. Regardless of how general or explicit the monitoring program, planners typically face resource or other constraints.

Strategy: Where feasible, coordinate development and implementation of PM\&E monitoring programs with existing ocean data portals in the planning area. Ideally, data portals developed to support ocean planning include relevant data to support monitoring and are updated periodically and accessible to the public. For more information on ocean data portals see "Creating and Using Data Portals to Support Ocean Planning."

\section{BEST PRACTICE: EVALUATE THE METRICS ESTABLISHED}

PM\&E evaluation refers to defining and conducting various analyses of information collected or produced from the monitoring program. The resulting information products are used to assess ocean plan performance and state-of-the-system to inform how the ocean plan will be updated as part of the planning and adaptive management cycle. 


\section{LET DATA HELP WITH PM\&E INTEGRATION}

An early activity in many ocean planning processes is inventorying already available spatial data and identifying key gaps and non-spatial information. This is an opportunity for planners to include an initial assessment of the potential utility of these data to evaluate progress toward state-of-the-system objectives later in the planning cycle. Though preliminary, such an exercise would generally help drive PM\&E considerations earlier in the planning cycle and more specifically, could facilitate developing indicators and metrics at the appropriate phase.

Figure 9. Let data help with PM\&E integration.

Challenges: As with monitoring, the degree of evaluation rigor and relevance will be commensurate with the preceding components of the ocean plan. In any case, this issue of causality persists. To what degree can observed changes in socioeconomic, ecological and governance systems be attributed to ocean plan implementation (Figure 5)?

Strategy: Use evaluation to determine whether the significance of an observed changed condition warrants an ocean planning response, regardless of whether the change can be definitively attributed to plan implementation.

Example: The Haida Gwaii sub-regional ocean plan developed as part of the MaPP process seeks to foster shellfish aquaculture as a means of sustainable development. The plan identifies the potential effects of ocean acidification as an explicit concern for this opportunity. In this case, ocean conditions and their effects on shellfish aquaculture are monitored so that if changes in ocean $\mathrm{pH}$ threaten shellfish aquaculture viability, planners can react to that condition and adjust the plan as necessary.

\section{STAKEHOLDER ENGAGEMENT}

The principles of ocean planning emphasize effective stakeholder engagement throughout the planning cycle as foundational for the process to be sufficiently transparent to produce a plan that is broadly accepted, credible and durable.

\section{BEST PRACTICE: ENGAGE STAKEHOLDERS THROUGHOUT PM\&E DEVELOPMENT AND IMPLEMENTATION}

The same principle is at the foundation of the PM\&E aspects of ocean planning. Stakeholder input is part of understanding how social systems and priorities evolve.

Challenges: In practice, there are considerable institutional and pragmatic challenges for stakeholder engagement that effectively balance the need for transparency and inclusion with political priorities and resource constraints, including funding, schedule and capacity.

Strategy: In addition to engaging stakeholders in ocean plan development (e.g., identifying objectives and indicators), solicit stakeholder feedback as a data source to support PM\&E in the implementation and evaluation phases.

Example: To advance the Massachusetts Ocean Management Plan PM\&E framework (Appendix B), practitioners developed a replicable stakeholder perception survey to be administered as part of the five-year plan review cycle. The survey was designed specifically to inform cyclic ocean plan review by collecting information from stakeholders on particular performance metrics, such as progress on science and data priorities, stakeholder engagement opportunities, data access, and overall progress toward plan goals. 


\section{BEST PRACTICE: INFORM STAKEHOLDERS REGULARLY ON PLAN IMPLEMENTATION PROGRESS}

Ocean planning principles also generally support some form of regular reporting to allow stakeholders to understand how plan implementation is progressing.

Challenges: The value and purpose of regular progress reporting by planning authorities may seem readily apparent, yet in practice it can be difficult to do effectively and meaningfully. Certain kinds of progress reporting, such as an accounting of whether certain management actions were done, can be relatively straightforward, though regular communication can still be challenging. More complex kinds of progress reporting, such as whether permitting processes are improving, may be difficult to demonstrate, especially early in plan implementation.

Strategy: Show and report intermediate returns from the process when possible, being clear that most benefits will come from long term outcomes. This helps to keep stakeholders engaged and focused on the long term.

Example: The state of Washington's online plan development progress reporting tool (Figure 10) organizes the actions they are taking as part of the plan development process and provides linkages between their work and the overall process.

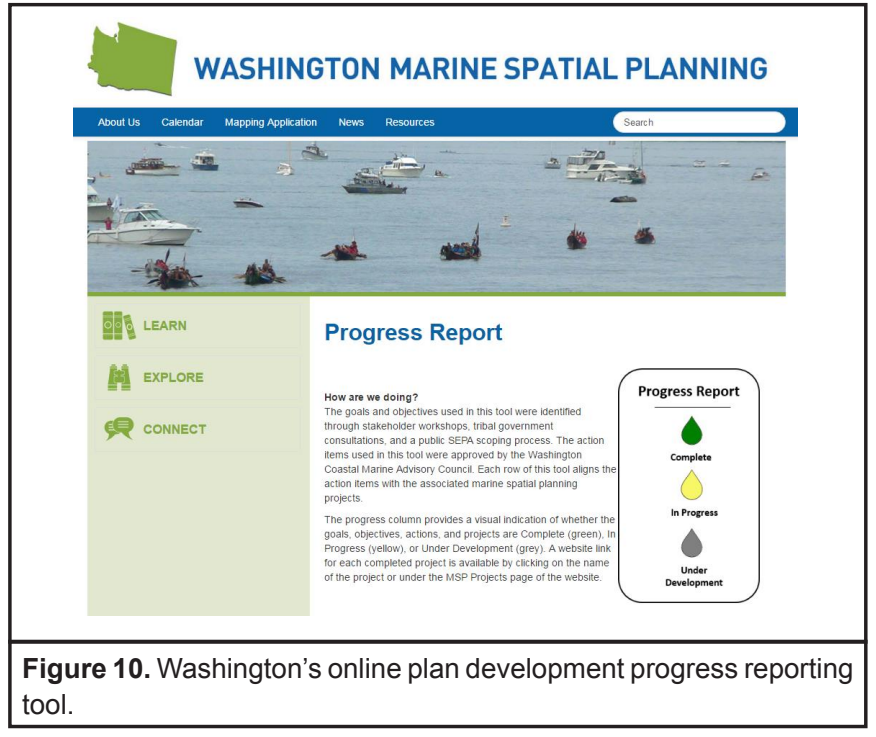

\section{MOVING FORWARD}

$P M \& E$ is the engine for adaptive management in ocean planning. If done thoroughly, it sets up accountability for planning authorities and stakeholders to agree on desired outcomes and demonstrate progress toward them. It demands at least a minimum level of specificity.

With ample theory to inform us and an increasing body of applied work, what will it take to shift PM\&E from being a planning afterthought toward an integrated overlay of the larger iterative planning cycle? We hope the information offered in this paper helps spark continued dialogue among ocean planning practitioners and stakeholders on this important topic. 


\section{APPENDIX A. PLANNING RESOURCES}

\begin{tabular}{|c|c|c|}
\hline Plan/Process & Planning Authority & Key Planning Documents \\
\hline $\begin{array}{l}\text { Connecticut Long Island } \\
\text { Sound Blue Plan }\end{array}$ & $\begin{array}{l}\text { Connecticut Department of } \\
\text { Energy and Environmental } \\
\text { Protection }\end{array}$ & $\begin{array}{l}\text { - } \frac{\text { Blue Plan Website }}{\text { Enabling Legislation }} \\
\text { - } \frac{\text { Options for Developing Marine Spatial }}{\text { Planning in Long Island Sound }}\end{array}$ \\
\hline $\begin{array}{c}\text { Hawaii Ocean Resources } \\
\text { Management Plan }\end{array}$ & $\begin{array}{l}\text { Hawaii Coastal Zone } \\
\text { Management Program }\end{array}$ & $\begin{array}{l}\text { - } \underline{\text { ORMP Website }} \\
\text { 2013 HI Ocean Resources Management Plan } \\
\underline{\text { Update }}\end{array}$ \\
\hline $\begin{array}{c}\text { Marine Plan Partnership for } \\
\text { the North Pacific Coast }\end{array}$ & $\begin{array}{l}\text { MaPP Partnership between } \\
\text { the Province of British } \\
\text { Columbia and } 17 \text { member } \\
\text { First Nations }\end{array}$ & $\begin{array}{l}\text { - } \\
\text { - } \\
\text { - } \\
\text { Haida Gegional Action Framework }\end{array}$ \\
\hline $\begin{array}{l}\text { Massachusetts Ocean } \\
\text { Management Plan }\end{array}$ & $\begin{array}{l}\text { Massachusetts Executive } \\
\text { Office of Energy and } \\
\text { Environmental Affairs }\end{array}$ & 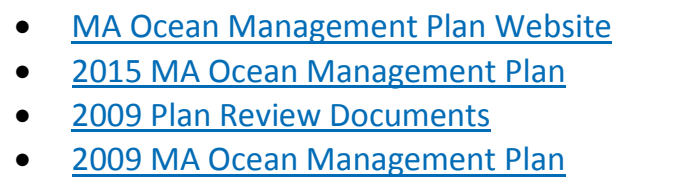 \\
\hline $\begin{array}{c}\text { Mid-Atlantic Ocean Action } \\
\text { Plan }\end{array}$ & $\begin{array}{l}\text { Mid-Atlantic Regional } \\
\text { Planning Body }\end{array}$ & - $\quad$ Mid-A Ocean Action Plan Website \\
\hline Northeast Ocean Plan & $\begin{array}{l}\text { Northeast Regional Planning } \\
\text { Body }\end{array}$ & - $\quad$ NE Ocean Plan Website \\
\hline Oregon Territorial Sea Plan & $\begin{array}{l}\text { Oregon Department of Land } \\
\text { Conservation and } \\
\text { Development }\end{array}$ & - $\underline{\text { Territorial Sea Plan Website }}$ \\
\hline $\begin{array}{c}\text { Rhode Island Ocean Special } \\
\text { Area Management Plan }\end{array}$ & $\begin{array}{l}\text { Rhode Island Coastal } \\
\text { Resources Management } \\
\text { Council }\end{array}$ & $\begin{array}{l}\text { - } \frac{\text { OSAMP Website }}{\text { First Biannual Assessment of the RI OSAMP }} \\
\text { - } \frac{\text { Plan Process }}{\text { Case Study: The RI OSAMP 2008-2015: From }} \\
\text { Inception through Implementation }\end{array}$ \\
\hline $\begin{array}{l}\text { United Kingdom Marine } \\
\text { Planning }\end{array}$ & $\begin{array}{l}\text { United Kingdom Marine } \\
\text { Management Organisation }\end{array}$ & $\begin{array}{l}\text { - UK Marine Planning Website } \\
\text { - } \frac{\text { UK Marine Policy Statement }}{\text { East Inshore and Offshore Marine Plans }} \\
\text { - } \frac{\text { Website }}{\text { East Inshore and Offshore Marine Plans }} \\
\text { Implementation and Monitoring Plan }\end{array}$ \\
\hline $\begin{array}{l}\text { Washington State Marine } \\
\text { Spatial Planning }\end{array}$ & $\begin{array}{l}\text { Washington State Ocean } \\
\text { Caucus }\end{array}$ & $\begin{array}{l}\text { - WA MSP Website } \\
\text { - WA Marine Spatial Plan Draft Contents } \\
\text { - Wanuary 2016) } \\
\text { Washington's Pacific Coast MSP Actions List }\end{array}$ \\
\hline
\end{tabular}




\section{APPENDIX B. MASSACHUSETTS PM\&E FRAMEWORK}

For the Massachusetts Ocean Management Plan, development of the PM\&E framework occurred over the course of two ocean planning cycles. While the 2009 plan did not explicitly incorporate PM\&E considerations from the start, it identified a suite of indicators and called for additional development of PM\&E going forward. The 2015 plan update included a more robust PM\&E implementation framework (see figure below). In its continuing work to operationalize the framework, the state has since defined clearer linkages among goals, metrics and indicators to facilitate overall plan assessment to guide subsequent plan revisions (see attached framework).

Diagram 1 from the 2015 Massachusetts Ocean Management Plan, shows the relationship between process and state-of-the-system aspects of the iterative ocean planning cycle.

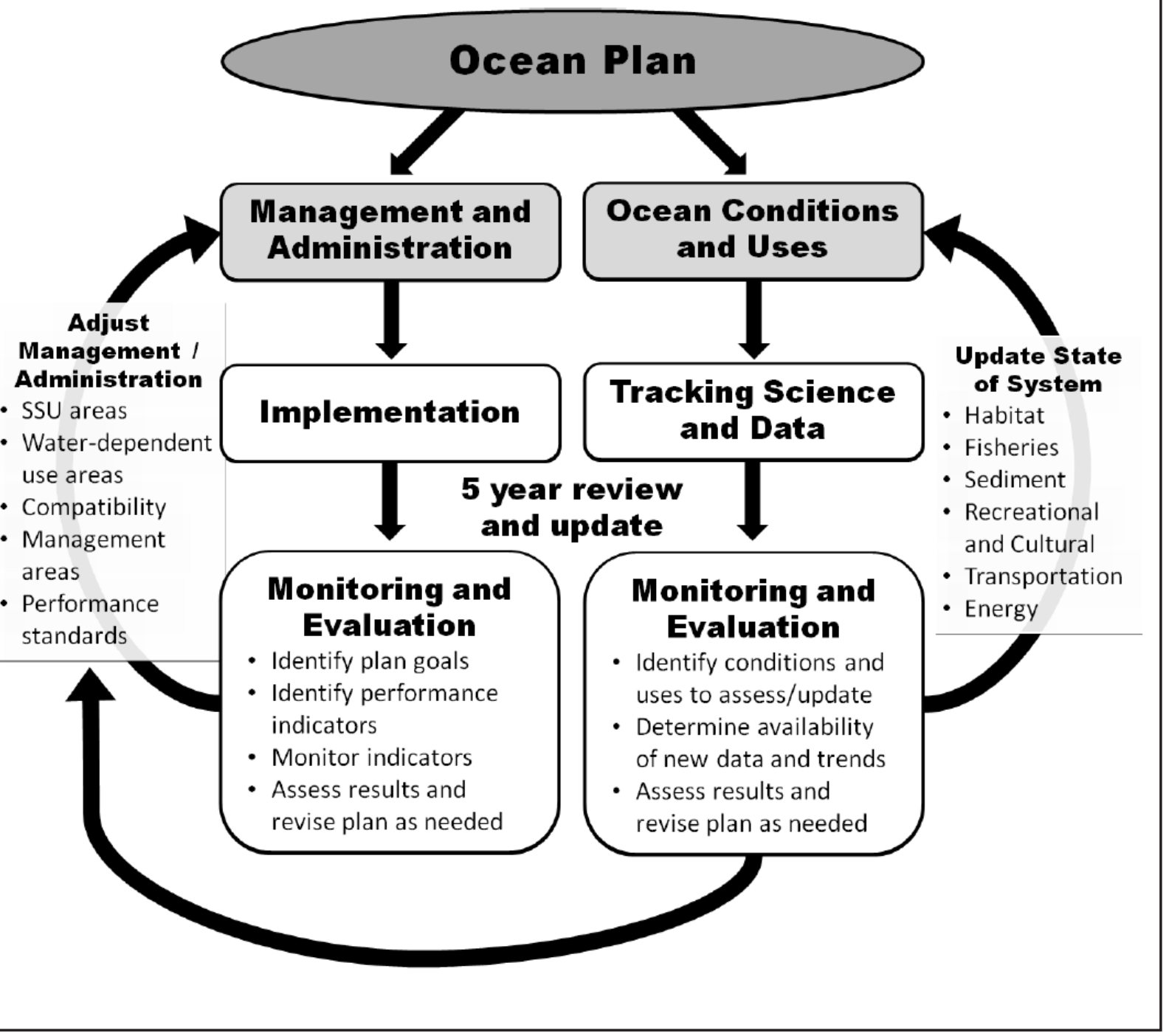




\section{MA Ocean Plan Performance Monitoring \& Evaluation - Final Framework Track 1 Plan Management and Administration}

\section{Framework Components}

The overall PM\&E framework outlines a logic flow that links Plan implementation to evaluating progress toward Plan goals. The information presented here focuses on Track 1. Components of the framework are briefly described below. Figure 1 illustrates the relationship and potential efficiencies among the framework components. It is the intent of the Office of CZM to have this PM\&E framework is informed by the best and most current science, mapping, and professional judgment of the specialists forming the technical work groups. The metrics listed may be quantitative or qualitative (descriptive), depending on the information gathered to answer the question. Additionally it is important to note that most of the metrics will be accompanied by a narrative describing the process.

- Goals define the overall outcomes the Plan aims to achieve. "What does the plan strive to accomplish?" (see page 2 for the four goals defined by the Plan)

- Indicators help gauge progress toward achieving Plan goals. "How will we know the degree to which management and implementation actions are supporting Plan goals?" The Plan identifies five main indicator themes (see page 2) and states that indicators are to be considered and modified as appropriate during development and subsequent revision of the monitoring and evaluation framework.

- Key management questions provide a shared language for the state, OAC/SAC and stakeholders to ask "What management/administrative questions do we need to answer to understand the status of indicators and, ultimately, progress toward Plan goals?"

- Metrics define the information needed to respond to the question "What data/information is necessary to answer the management question?"

- Approaches are the mechanisms for collecting the information defined by each metric. "How do we get that information?" Each approach has elements of collection, analysis, and coordination. Most approaches identified in the next section involve collecting/analyzing existing agency data, but some require collection of additional data (e.g., through research or a perception survey).

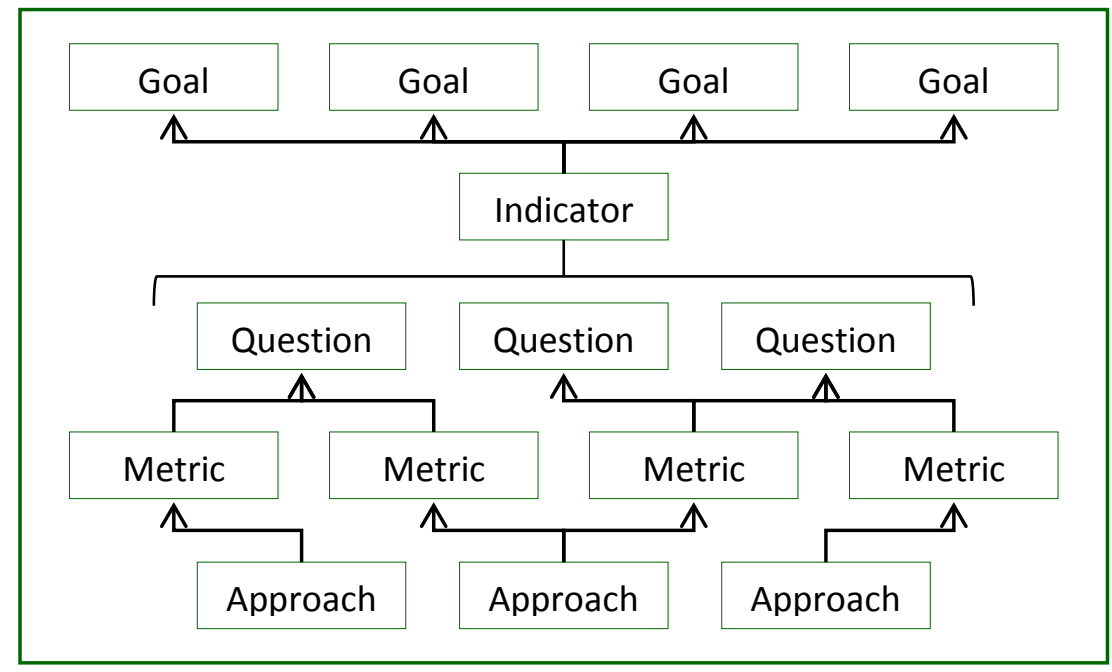

Figure 1. PM\&E Framework Components and Efficiencies. One metric often addresses multiple management questions, and a limited number of approaches can be used to gather data for multiple metrics. 
Plan Goals

1. Balance and protect the natural, social, cultural, historic, and economic interests of the marine ecosystem through integrated management.

2. Recognize and protect biodiversity, ecosystem health, and the interdependence of ecosystems.

3. Support wise use of marine resources, including renewable energy, sustainable uses, and infrastructure.

4. Incorporate new knowledge as the basis for management that adapts over time to address changing social, technological, and environmental conditions.

Indicators

1. Status of special, sensitive, or unique (SSU) resources and concentrations of waterdependent uses (WDU)

2. Progress on Science Framework priorities, data acquisition, and mapping efforts

3. Development and implementation of ocean management and governance tools

4. Status of Ocean Resources and Waterways Trust

5. Stakeholder and public involvement in the planning process and ongoing implementation 


\section{Information Gathering Framework by Indicator Theme}

\section{Status of special, sensitive, or unique (SSU) resources and concentrations of water-dependent uses (WDU)}

\section{Linkage between Indicator Theme and Plan Goals}

- Goal 1: Provides insight into how select natural, social, cultural, historic, and economic interests have changed (using SSUs and WDUs as proxies) and supplies information to evaluate whether these interests are appropriately balanced.

- Goal 2: Provides insight into the level of biodiversity (through the number of SSUs) and ecosystem health (through the expansion/contraction of SSUs) and supplies information to evaluate whether these are sufficiently recognized and protected.

- Goal 3: Provides insight into the use of marine resources (using WDUs as proxies) and supplies information to evaluate whether these resources are being used wisely.

- Goal 4: Provides insight into whether new knowledge about social, technological, and environmental conditions (using Track 2 evaluation of SSUs and WDUs as a proxy) is being incorporated to drive adaptive management.

\begin{tabular}{|c|c|c|c|}
\hline Questions & Metrics & Approach & Info Gatherer \\
\hline $\begin{array}{l}\text { Over the past } 5 \text { years, what changes in } \\
\text { management approaches (areal extent, siting or } \\
\text { performance standards) have been made based } \\
\text { on the status of an SSU/WDU? }\end{array}$ & \multirow{2}{*}{$\begin{array}{l}\text { - Changes in areal extent of existing mapped } \\
\text { SSUs/WDUs } \\
\text { - Changes in performance and/or siting } \\
\text { standards } \\
\text { - \# New SSU/WDU defined } \\
\text { - \# of current SSUs/WDUs removed } \\
\text { - \# and list of management approaches } \\
\text { considered but not included in plan update }\end{array}$} & \multirow[t]{2}{*}{$\begin{array}{l}\text { Compilation and analysis of } \\
\text { agency data through topical } \\
\text { technical work group analysis } \\
\text { (i.e., Track 2) }\end{array}$} & \multirow[t]{2}{*}{$\begin{array}{l}\text { Technical Work } \\
\text { Groups }\end{array}$} \\
\hline $\begin{array}{l}\text { Based on recent assessment of data, what } \\
\text { changes in management approaches (areal } \\
\text { extent, siting or performance standards) are being } \\
\text { considered to the status of an SSU/WDU? }\end{array}$ & & & \\
\hline $\begin{array}{l}\text { Have applicants provided alternative data/maps } \\
\text { for current SSUs/WDUs? }\end{array}$ & $\begin{array}{l}\text { - Changes in extent of SSU/WDU maps } \\
\text { - Number and type of alternate data/maps } \\
\text { provided by applicants }\end{array}$ & $\begin{array}{l}\text { Record keeping and } \\
\text { compilation of agency data }\end{array}$ & $\begin{array}{l}\text { CZM with } \\
\text { agencies }\end{array}$ \\
\hline $\begin{array}{l}\text { What were the permit outcomes of applications } \\
\text { for work in SSUs/WDUs? }\end{array}$ & $\begin{array}{l}\text { - \# of permit applications, including status } \\
\text { and/or ultimate outcome of project }\end{array}$ & $\begin{array}{l}\text { Record keeping and } \\
\text { compilation of agency data }\end{array}$ & $\begin{array}{l}\text { CZM with } \\
\text { agencies }\end{array}$ \\
\hline $\begin{array}{l}\text { Are new data being incorporated into permits and } \\
\text { management decisions? }\end{array}$ & $\begin{array}{l}\text { - Number of permit processes where new } \\
\text { data, not available through MORIS, were } \\
\text { considered }\end{array}$ & $\begin{array}{l}\text { Record keeping and } \\
\text { compilation of agency data }\end{array}$ & $\begin{array}{l}\text { CZM with } \\
\text { agencies }\end{array}$ \\
\hline
\end{tabular}




\section{Information Gathering Framework by Indicator Theme}

\section{Progress on Science Framework priorities, data acquisition, and mapping efforts}

\section{Linkage between Indicator Theme and Plan Goals}

- Goal 1: Provides insight into the condition of natural, social, cultural, historic, and economic interests of the marine ecosystem (through progress on Science Framework priorities) and helps evaluate whether these are appropriately balanced and protected.

- Goal 2: Provides insight into biodiversity, ecosystem health, and the interdependence of ecosystems.

- Goal 3: Provides insight into the success of management of marine resources.

- Goal 4: Provides insight into whether new knowledge about 1) social, technological, and environmental conditions and 2) adaptive management techniques (using progress on Science Framework priorities as a proxy) is being collected and made available for consideration.

\begin{tabular}{|c|c|c|c|}
\hline Questions & Metrics & Approach & Info Gatherer \\
\hline $\begin{array}{l}\text { What progress has been made by the } \\
\text { Commonwealth on the current science priorities } \\
\text { in the Ocean Plan? }\end{array}$ & $\begin{array}{l}\text { - \# and list of actions taken, outcomes, and level } \\
\text { of progress on each priority. } \\
\text { - \#and list of types of data applications resulting } \\
\text { from progress on science priorities. }\end{array}$ & $\begin{array}{l}\text { Record keeping and } \\
\text { compilation of agency data; } \\
\text { Perception survey }\end{array}$ & $\begin{array}{l}\text { Technical Work } \\
\text { Groups, } \\
\text { CZM with } \\
\text { agencies }\end{array}$ \\
\hline $\begin{array}{l}\text { Who are the partners and stakeholders associated } \\
\text { with the science framework projects? }\end{array}$ & $\begin{array}{l}\text { - \# and list of partners and stakeholders by } \\
\text { project with roles identified } \\
\text { - \# and list of engagement opportunities (e.g. } \\
\text { informational meetings, workshops) and } \\
\text { details on how public input was incorporated. }\end{array}$ & $\begin{array}{l}\text { Record keeping and } \\
\text { compilation of agency data }\end{array}$ & $\begin{array}{l}\text { CZM with } \\
\text { agencies }\end{array}$ \\
\hline $\begin{array}{l}\text { Do managers, researchers, and stakeholders feel } \\
\text { adequate progress has been made on science } \\
\text { priorities? }\end{array}$ & - Results of perception survey & Perception Survey & $\begin{array}{l}\text { CZM with third } \\
\text { party }\end{array}$ \\
\hline $\begin{array}{l}\text { How public and accessible were the data } \\
\text { generated in support of the Ocean Plan? }\end{array}$ & $\begin{array}{l}\text { - \# and List of datasets available on MORIS } \\
\text { - Date new dataset is added to MORIS } \\
\text { - Frequency and number of unique visits to } \\
\text { MORIS }\end{array}$ & $\begin{array}{l}\text { Compilation and analysis of } \\
\text { agency data }\end{array}$ & $\begin{array}{l}\text { CZM with } \\
\text { agencies }\end{array}$ \\
\hline
\end{tabular}




\section{Development and implementation of ocean management and governance tools}

\section{Linkage between Indicator Theme and Plan Goals}

- Goal 1: Provides insight on how natural, social, cultural, historic, and economic interests of the marine ecosystem are being balanced and protected (through consideration of tradeoff and compatibility analyses) and supplies information to evaluate whether the management/governance structures are sufficiently integrated.

- Goal 2: Provides insight into how biodiversity and ecosystem health are considered in the management/governance structures (through use of tools that characterize and evaluate ecosystem services).

- Goal 3: Provides insight into how marine resource uses are considered in the management/governance structures (through consideration of permitting processes, and use of tools that characterize and evaluate uses/ecosystem services).

- Goal 4: Provides insight on how new knowledge and advances in adaptive management are being incorporated into the management and governance structure (through consideration of proposed and revised management policies and actions) and supplies information to evaluate whether the management framework is sufficient to adapt to changing social, technological, and environmental conditions.

\begin{tabular}{|c|c|c|c|}
\hline Questions & Metrics & Approach & Info Gatherer \\
\hline $\begin{array}{l}\text { Does the experience of managers, regulated } \\
\text { community, and stakeholders in implementing the } \\
\text { plan indicate a streamlined (efficient and } \\
\text { effective) permitting process? }\end{array}$ & $\begin{array}{l}\text { Distribution of scores given by managers, } \\
\text { regulated community, and stakeholders in a } \\
\text { perception survey }\end{array}$ & Perception survey & $\begin{array}{l}\text { CZM with third } \\
\text { party }\end{array}$ \\
\hline How effective is interagency cooperation? & $\begin{array}{l}\text { - Analysis of results of perception survey } \\
\text { - \# and list of projects (management or } \\
\text { permitting) that required interagency } \\
\text { coordination and their outcomes }\end{array}$ & $\begin{array}{l}\text { Perception survey } \\
\text { Compilation and analysis of } \\
\text { agency data } \\
\text { Describe } 1-2 \text { case studies to } \\
\text { reflect interagency } \\
\text { coordination }\end{array}$ & $\begin{array}{l}\text { CZM with third } \\
\text { party }\end{array}$ \\
\hline $\begin{array}{l}\text { Are there new initiatives, approaches and policies } \\
\text { that pertain to or warrant changes to the plan } \\
\text { (including research priorities, goals, use of } \\
\text { adaptive management, consideration of climate } \\
\text { change, particularly adaptation and resiliency)? }\end{array}$ & $\begin{array}{l}\text { - \# and list of relevant new initiatives, } \\
\text { approaches, and policies. }\end{array}$ & Legal research and analysis & $\begin{array}{l}\text { CZM with } \\
\text { agencies }\end{array}$ \\
\hline $\begin{array}{l}\text { Have managers effectively required permitees to } \\
\text { use best practices (BPs) to avoid use conflicts } \\
\text { during and after the permitting process? }\end{array}$ & $\begin{array}{l}\text { - \# and list of projects subject to the Plan and } \\
\text { respective use of BPs }\end{array}$ & $\begin{array}{l}\text { Compilation of agency data; } \\
\text { Describe 1-2 pre-application } \\
\text { case studies } \\
\text { Perception survey }\end{array}$ & $\begin{array}{l}\text { CZM with } \\
\text { agencies }\end{array}$ \\
\hline
\end{tabular}

MA Ocean Plan Performance Monitoring \& Evaluation Framework 


\section{Information Gathering Framework by Indicator Theme}

\section{Status of Ocean Resources and Waterways Trust}

\section{Linkage between Indicator Theme and Plan Goals}

- Goal 1: Provides insight on how natural, social, cultural, historic, and economic interests have been protected (through consideration of the use of trust $^{1}$ funds for enhancement, restoration, or improvement of marine habitat and resources, navigation, or fisheries).

- Goal 2: Provides insight into how trust funding has protected biodiversity, ecosystem health, and interdependence of ecosystems (through consideration of funds used for marine habitat and resource enhancement, environmental enhancement, and restoration).

- Goal 3: Provides insight into how trust funds have helped to protect biodiversity, ecosystem health, and interdependence of ecosystems (through analysis of the trust expenditures).

- Goal 4: Provides insight into how trust funds have supported adaptive management (through consideration of trust funding for fisheries management and other ocean management).

\begin{tabular}{|c|c|c|c|}
\hline Questions & Metrics & Approach & Info Gatherer \\
\hline $\begin{array}{l}\text { How has the Trust been utilized to advance } \\
\text { priorities to the Ocean Plan including, but not } \\
\text { limited to, science framework priorities? }\end{array}$ & $\begin{array}{l}\text { - \# and list of projects funded by Trust and their } \\
\text { outcomes } \\
\text { - \# and list of science priorities funded by Trust } \\
\text { - Total funds used }\end{array}$ & $\begin{array}{l}\text { Record keeping and } \\
\text { compilation of agency data }\end{array}$ & $\begin{array}{l}\text { CZM with } \\
\text { agencies }\end{array}$ \\
\hline $\begin{array}{l}\text { Has the Trust been utilized to support ocean } \\
\text { management efforts beyond the plan? }\end{array}$ & $\begin{array}{l}\text { - \# and list of projects funded by Trust and their } \\
\text { outcomes }\end{array}$ & Analysis of agency data & $\begin{array}{l}\text { CZM with } \\
\text { agencies }\end{array}$ \\
\hline $\begin{array}{l}\text { Have ocean development projects been subject to } \\
\text { the Ocean Development Mitigation Fee? }\end{array}$ & - \# and list of projects by fee category & $\begin{array}{l}\text { Record keeping and } \\
\text { compilation of agency data }\end{array}$ & $\begin{array}{l}\text { CZM with } \\
\text { agencies }\end{array}$ \\
\hline Were the activities of the Trust made public? & $\begin{array}{l}\text { - Date Information on Trust activities was } \\
\text { updated on EEA website }\end{array}$ & $\begin{array}{l}\text { Record keeping and } \\
\text { compilation of agency data }\end{array}$ & $\begin{array}{l}\text { CZM with } \\
\text { agencies }\end{array}$ \\
\hline
\end{tabular}

${ }^{1}$ The definition of the Trust in the Oceans Act:

"The priority for use of funds derived from compensation or mitigation for ocean development projects shall be to restore or enhance marine habitat and resources impacted by the project for which the compensation or mitigation shall have been received. The funds derived from compensation or mitigation related to public navigational impacts shall be dedicated to public navigational improvements; provided, however, that any funds for the enhancement of fisheries resources shall be directed to conduct fisheries restoration and management programs. Any other amounts credited to the fund shall be used, without further appropriation, only for the purposes of environmental enhancement, restoration and management of ocean resources"

MA Ocean Plan Performance Monitoring \& Evaluation Framework 


\section{Information Gathering Framework by Indicator Theme}

\section{Stakeholder and public involvement in the planning process and ongoing implementation}

\section{Linkage between Indicator Theme and Plan Goals}

- Goal 1: Provides insight to how the plan has addressed protecting and balancing existing and newly identified interests, particularly the social, cultural, historic, and economic, and indirectly natural interests (through consideration of stakeholder input related to each interest).

- Goal 2: Provides insight to how well biodiversity, ecosystem health, and the interdependence of ecosystems are understood and whether they are sufficiently protected as defined by societal value.

- Goal 3: Provides insight into the management of marine resources, including renewable energy, sustainable uses, and infrastructure (through stakeholder and public involvement and their perception of the success of management).

- Goal 4: Provides insight into the incorporation of new knowledge related to social, technological, and environmental conditions; and new knowledge related to adaptive management (through consideration of stakeholder perception of how well the plan incorporates knowledge of these conditions).

\begin{tabular}{|c|c|c|c|}
\hline Questions & Metrics & Approach & Info Gatherer \\
\hline $\begin{array}{l}\text { What were the opportunities for public and } \\
\text { stakeholder involvement in Ocean Plan } \\
\text { implementation and in the Ocean Plan } \\
\text { review/update process? }\end{array}$ & $\begin{array}{l}\text { - \# and List of engagement opportunities (e.g., } \\
\text { informational meetings, workshops) and details } \\
\text { on how public input was considered } \\
\text { - Length of comment periods } \\
\text { - Level of participation }\end{array}$ & $\begin{array}{l}\text { - Record keeping and } \\
\text { compilation of agency } \\
\text { data }\end{array}$ & $\begin{array}{l}\text { CZM with } \\
\text { agencies and } \\
\text { third party }\end{array}$ \\
\hline $\begin{array}{l}\text { How has the Plan been updated to address public } \\
\text { and stakeholder input? }\end{array}$ & $\begin{array}{l}\text { - \# and list of comments made } \\
\text { - How comments were addressed in the Plan }\end{array}$ & $\begin{array}{l}\text { - Analysis of public } \\
\text { comments }\end{array}$ & $\begin{array}{l}\text { CZM with } \\
\text { agencies and } \\
\text { third party }\end{array}$ \\
\hline $\begin{array}{l}\text { Does the experience of the regulated community } \\
\text { and stakeholders indicate satisfaction with the } \\
\text { involvement processes/opportunities, and the } \\
\text { results, in Plan implementation and } \\
\text { review/update? }\end{array}$ & - Results of perception survey & - Perception survey & $\begin{array}{l}\text { CZM with } \\
\text { agencies and } \\
\text { third party }\end{array}$ \\
\hline
\end{tabular}

